\title{
ANALISIS KASUS MANAJEMEN KOMUNIKASI KRISIS: SERANGAN WARGANET ATAS PENYELENGGARAAN HARD ROCK FM FASHION ROCKS 2020 DI DALAM MRT JAKARTA
}

\section{CRISIS COMMUNICATION MANAGEMENT CASE ANALYSIS: CITIZENS ATTACK ON THE ORGANIZATION HARD ROCK FM FASHION ROCKS 2020 IN MRT JAKARTA}

\author{
Ibnu Akmal ${ }^{{ }^{*}}$ \\ ${ }^{1}$ Manajemen Ilmu Komunikasi FISIP Universitas Indonesia \\ *Korespondensi: Ibnu Akmal, Email: ibnuakmal@gmail.com \\ (Diterima oleh Dewan Redaksi: 07-06-2021) \\ (Dipublikasikan oleh Dewan Redaksi: 15-10-2021)
}

\begin{abstract}
The presence of Mass Rapid Transit or Moda Raya Terpadu (MRT) in Jakarta since March 2019 is not only attracting the users of public transportation but also the private sector company in organizing activities that required public attention or publicity. The annual Hard Rock FM Fashion Rocks event which held in an ongoing MRT carriage in early 2020 turned into anger among users of public transportation and left bad comments on social media, as well as negative news in the online media. The delay in response and the company's unmatch response expectations added this case to an unexpected crisis until the management that represented by Iwet Ramadhan as the Head of MRA Media Business Growth apologized personally on social media. Through five steps of the case analysis method, namely framing, labeling, summarizing, synthesizing, and concluding, it can be analyzed if only Hard Rock FM is more sensitive to the needs of MRT users, the scheduled time or date, and responds quickly to complaints that arise, it will minimize the turnover of netizens on social media. However, the step of apologizing by focusing on the conditions of the aggrieved parties is very appropriate as a form of sympathy and effective compensation.
\end{abstract}

Keywords: Crisis Communication; Netizen; Social Media; Apology; Hard Rock FM

\begin{abstract}
ABSTRAK
Kehadiran Mass Rapid Transit atau Moda Raya Terpadu (MRT) di Jakarta sejak bulan Maret 2019 tidak hanya menarik perhatian masyarakat pengguna transportasi umum, namun juga pihak swasta dalam menyelenggarakan kegiatan yang membutuhkan perhatian khalayak atau publisitas. Acara tahunan Hard Rock FM Fashion Rocks yang diadakan di dalam gerbong MRT yang sedang berjalan pada awal tahun 2020 berubah menjadi kemarahan khalayak pengguna moda transportasi umum dan meninggalkan komentar buruk di media sosial, serta pemberitaan negatif di media online. Keterlambatan respon dan tanggapan yang dianggap tidak sesuai harapan khalayak menambah kasus ini menjadi krisis yang tidak terduga, hingga manajemen yang diwakili oleh Iwet Ramadhan selaku Head of Business Growth MRA Media meminta maaf secara pribadi melalui media sosial. Melalui lima langkah metode analisis kasus yaitu framing, labeling, summarizing, synthesizing dan concluding maka dapat disimpulkan jika Hard Rock FM lebih peka terhadap kebutuhan pengguna MRT, jadwal penyelenggaraan acara dan cepat tanggap atas keluhan yang muncul maka akan meminimalisasi bergulirnya kemarahan warganet di media sosial. Namun langkah meminta maaf dengan berfokus pada kondisi pihak-pihak yang dirugikan sangatlah tepat sebagai bentuk simpati dan kompensasi yang efektif.
\end{abstract}

Kata Kunci: Komunikasi Krisis; Warganet; Media Sosial; Permintaan Maaf; Hard Rock FM

Ibnu Akmal, 2021. Analisis Kasus Manajemen Komunikasi Krisis: Serangan Warganet Atas Penyelenggaraan Hard Rock FM Fashion Rocks 2020 di dalam MRT Jakarta. 


\section{PENDAHULUAN}

Percepatan akses internet dan kemajuan teknologi membawa perubahan bagi khalayak terutama dengan hadirnya beragam platform media sosial yang bisa diakses dengan sangat mudah melalui gawai yang dimiliki. Mengacu pada hasil survei Penetrasi dan Profil Perilaku Pengguna Internet Indonesia oleh Asosiasi Penyelenggara Jasa Internet Indonesia (APJII) di tahun 2018, sebanyak 171,17 juta jiwa dari total 264,16 juta penduduk Indonesia merupakan pengguna Internet, dan Facebook menjadi platform media sosial yang sering dikunjungi $(50,7 \%)$, disusul Instagram (17,8\%), YouTube $(15,1 \%)$ serta Twitter (1,7\%) (APJII, 2019). Sementara menurut riset We Are Social dan Hootsuite di bulan Januari 2020, sebanyak 160 juta penduduk Indonesia adalah pengguna aktif media sosial yang rata-rata menghabiskan waktu lebih dari tiga jam setiap hari untuk bermedia sosial dan sebanyak 99\% pengguna media sosial Indonesia mengakses melalui telepon seluler (We Are Social \& Hootsuite, 2020). Tingginya minat pengguna media sosial di tanah air juga menjadikan Indonesia menjadi negara pengguna Instagram terbesar ke-4 di dunia (Hamdan, 2019).

Tidak semua penggunaan media bersifat sosial, misalnya menulis dokumen. Namun jika terjadi interaksi dalam bentuk perbincangan melalui kolom komentar dan saling merespon maka bersifat sosial dan menjadi bentuk komunikasi karena adanya pertukaran simbol dan makna pada simbolsimbol tersebut (Fuchs, 2017). Miller, et al (2016) memandang media sosial sebagai bagian integral dari kehidupan sehari-hari melalui cara yang sama seperti saat khalayak dapat memahami percakapan telepon sebagai bagian dari kehidupan offline dan bukan bagian dari ruang kehidupan yang terpisah. Komunikasi yang berulang kali terjadi di media sosial kemudian melibatkan perasaan memiliki dan interaksi layaknya teman, hingga mengubah bentuk sosial menjadi komunitas (Miller et al. 2016).

Kemudahan khalayak berkomunikasi melalui media sosial memberikan dua sisi dampak yang berbeda, di satu sisi khalayak dapat dengan mudahnya memperoleh informasi terbaru secara cepat namun di lain sisi khalayak pengguna media sosial dapat menyebarkan informasi secara cepat dan lebih luas tanpa batasan ruang dan waktu. Hal ini dapat menjadi kerugian jika isu yang disebarkan adalah isu negatif perusahaan. Aksi demonstrasi besar para pengemudi transportasi umum angkutan darat pada 22 Maret 2016 yang berbuntut aksi anarkis para pengemudi taksi Blue Bird, menimbulkan kemarahan dan kekecewaan pengguna media sosial atau warganet hingga menimbulkan krisis bagi Blue Bird. Secara cepat berbagai foto dan video rekaman aksi anarkis tersebar luas melalui media sosial dan menjadikan krisis Blue Bird sebagai trending topic di lini masa Twitter. Suryani dan Sagiyanto (2018) menjelaskan memang butuh waktu untuk dapat mengembalikan nama baik perusahaan serta kepercayaan publik, dan Blue Bird kembali memanfaatkan platform media sosial untuk menjalankan kampanye bertajuk "Berbenah Untuk Berubah" di YouTube yang menjadi bagian dari strategi manajemen krisis "Reimagining Blue Bird". Video yang diunggah 25 September 2016 ini kemudian berhasil merebut simpati masyarakat dan mengembalikan reputasi perusahaan.

Kekuatan media sosial warganet yang menimbulkan krisis bagi perusahaan juga dapat dilihat pada kasus \#UninstallBukalapak. Kicauan pendiri Bukalapak, Achmad Zaky di Twitter pada 13 Februari 2019 menjadi perdebatan. Cuitan Zaky mengenai frasa "Presiden baru" ditanggapi warganet telah memojokkan Presiden Joko Widodo (Jokowi) dan Zaenudin (2019) melalui artikelnya di situs Tirto.id menyatakan 
dalam waktu dua hari hingga Jumat, 15 Februari 2019 sebanyak 52.471 kicauan warganet dengan tanda pagar \#UninstallBukalapak telah terekam oleh mesin analisis media sosial, Drone Emprit muncul di media sosial Twitter. Kampanye warganet ini berhasil menimbulkan krisis dengan adanya gerakan menghapus aplikasi Bukalapak di gawai telepon seluler yang dimiliki. Dalam penyelesaian krisis \#UninstallBukalapak maka Achmad Zaky segera menghapus tweet yang kontroversial dan melakukan pertemuan secara langsung dengan Presiden Joko Widodo untuk meminta maaf. Usai pertemuan tersebut, Presiden Joko Widodo mengajak masyarakat untuk mengabaikan gerakan \#UninstallBukalapak yang marak di media sosial (Damayanti, 2020).

Awal tahun 2020 kejadian serupa kembali terjadi ketika warganet memprotes kegiatan Fashion Rocks yang diadakan oleh Hard Rock FM pada Jumat, 31 Januari 2020. Fashion Rocks yang merupakan bentuk eksistensi tahunan Hard Rock FM dalam mendukung industri kreatif gaya hidup anak muda melalui fashion show, menggunakan lokasi-lokasi yang sentral dan strategis sehingga dapat dilihat oleh masyarakat luas dan tahun 2020 kegiatan Fashion Rocks diadakan di dalam gerbong MRT yang sedang berjalan. Kegiatan ini dalam waktu singkat berhasil pusat perhatian publik, namun dikarenakan emosi warganet yang tidak dapat menggunakan moda transportasi umum MRT di jadwal pulang bekerja yaitu pukul 18.00 WIB dan sebanyak dua gerbong yang sengaja diperuntukkan untuk kegiatan ini. Warganet juga mengeluhkan suasana stasiun MRT Bundaran Hotel Indonesia yang penuh dengan panitia, media, undangan, dan para model sehingga mengganggu mobilitas penumpang, ditambah pengguna MRT akhirnya secara terpaksa harus berdesak-desakan dan memperebutkan gerbong kereta yang tersisa. Dalam waktu singkat warganet menyebarkan permasalahan ini melalui tulisan, foto dan video di media sosial hingga menimbulkan krisis bagi Hard Rock FM sebagai penyelenggara. Jika menelusuri tautan tanda pagar "\#HRFMFashionRocks" di Twitter dan Instagram, tercatat kurang lebih 411 komentar dan 299 Quote Tweets ditemukan di media sosial Twitter serta 650 komentar bermunculan di Instagram yang mayoritas berisi ujaran kemarahan warganet. Berbagai komentar negatif dan penuh kemarahan hingga kini masih dapat ditemukan di media sosial, termasuk pemberitaan media online tanah air yang mengangkat aksi protes warganet terhadap kegiatan ini.

Berdasarkan uraian di atas, fenomena kekuatan warganet di media sosial memang nyata adanya dan memiliki peran besar dalam menggerakkan opini para pengguna media sosial lain yang tentu dapat menjadi krisis berkepanjangan bagi organisasi atau perusahaan jika tidak segera diselesaikan. Penelitian ini bertujuan untuk mengetahui strategi Hard Rock FM sebagai penyelenggara utama kegiatan Fashion Rocks 2020 - The 1st ever Fashion Show on MRT Jakarta dalam menanggapi krisis yang muncul dan penyelesaiannya dengan warganet di media sosial. 


\section{LANDASAN TEORI}

\section{A. Krisis}

Coombs (2015) mendefinisikan krisis sebagai persepsi tentang peristiwa atau kejadian tidak terduga yang mengancam ekspektasi penting dari para stakeholders terkait isu-isu penting seperti kesehatan, keselamatan, lingkungan, dan ekonomi, serta dapat berdampak serius pada kinerja organisasi dan menghasilkan hasil negatif. Sebagian besar krisis bersifat perseptual, jika stakeholders meyakini terjadinya sebuah krisis maka organisasi berada dalam krisis. Krisis juga dinyatakan sebagai sebuah pelanggaran ekspektasi hingga menempatkan kinerja organisasi dalam risiko yang memberikan kerugian. Sehingga untuk menanganinya dipelukan manajemen krisis sebagai usaha untuk mencegah atau mengurangi hasil negatif dari krisis yang terjadi.

Tidak semua pengalaman buruk menjadi krisis bagi organisasi atau perusahaan. Ulmer et al (2019) menjelaskan tiga karakteristik dari studi klasik Hermann yang memisahkan krisis dari kejadiankejadian yang tidak menyenangkan lain seperti kejutan, ancaman dan waktu respon yang singkat. Suatu peristiwa yang meresahkan tidak dapat dianggap mencapai tingkat krisis tiga karakteristik tersebut. Dengan memahami persepsi stakeholders, tim krisis lebih siap untuk mengelola reaksi stakeholders terhadap krisis (Coombs, 2009).

Krisis Hard Rock FM timbul dengan mengalami proses dari sebuah kejadian yang mengejutkan, menimbulkan tingkat ancaman dan menyebabkan perusahaan harus bertindak cepat dalam memberikan respon. Lorenz (2000) dalam Chaos Theory and The Butterfly Effect in Crisis Management menjelaskan adanya keterbatasan dalam mengendalikan persepsi publik yang mudah dalam sebuah krisis. Teori ini menjelaskan adanya "ketergantungan yang peka terhadap kondisi awal" yang berarti sebuah aksi kecil dapat memulai serangkaian peristiwa yang kemudian dapat menimbulkan efek yang lebih besar dan tidak terduga. Dalam Je Cho (2012), Lorenz bermaksud menjelaskan bahwa deskripsi statistik dari suatu sistem yang dinamis kadang tidak sensitif terhadap kondisi atau situasi awal dan Butterfly Effect kemudian berkaitan erat dengan teori Chaos yang menggambarkan jika sempat terjadi sedikit perubahan di awal maka akan mengubah kondisi keseluruhan di bagian akhir secara dramatis atau hal-hal yang berkenaan dengan sistem yang tidak teratur. Dengan kemajuan perangkat teknologi dan kemudahan mengakses media sosial melalui internet, penting bagi perusahaan untuk terus memperhatikan keberadaan warganet dan mendengarkan suara mereka.

\section{B. Theory of Apology}

Permintaan maaf atau apology secara strategis sering digunakan dalam komunikasi krisis individu atau organisasi. Frandsen dan Johansen (2017) memfokuskan pada definisi dan tipologi permintaan maaf yang dikemukakan Nicholas Tavuchis yaitu tindak tutur menjadi bentuk permintaan maaf yang dapat dilakukan pertama kali dan bagian komunikasi verbal. Seperti semua jenis komunikasi, permintaan maaf melibatkan hubungan diadik atau hasil interaksi antara dua aktor, pelaku dan pihak yang merasa dirugikan. Tavuchis (1991) menyatakan empat konfigurasi struktural permintaan maaf, yaitu (1) One to One; Permintaan maaf interpersonal dari satu individu ke individu lain, (2) One to Many; Permintaan maaf dari individu ke kolektivitas, (3) Many to One; Permintaan maaf dari kolektivitas ke individu dan (4) Many to Many; Permintaan maaf dari satu kolektivitas ke kolektivitas lainnya. 
Hearit (2006) melakukan studi yang lebih rinci mengenai penggunaan permintaan maaf sebagai strategi bagi penyelesaian komunikasi krisis dengan menguraikan model berorientasi teoritis (theoreticallyoriented model) dan model yang lebih berorientasi praktis (practically-oriented model). Hearit menyatakan permintaan maaf sama efektifnya dengan strategi yang berfokus pada kondisi pihak yang dirugikan, seperti dalam bentuk simpati dan kompensasi (Smartsheet.com, 2021).

Frandsen dan Johansen (2017) merunut lima tahapan proses permintaan maaf Hearit sebagai (1) Adanya pelanggaran tatanan sosiokultural oleh individu, organisasi atau perusahaan, (2) Pihak yang bertanggung jawab atas pelanggaran tersebut dituduh bersalah oleh masyarakat, (3) Akibat tuduhan tersebut, timbul krisis legitimasi sosial antara pelaku yang bertanggung jawab atas kesalahan dan masyarakat, (4) Individu, organisasi, atau perusahaan yang bertanggung jawab atas kesalahan meminta maaf dan mengakui kesalahannya, dan (5) Jika permintaan maaf diterima oleh masyarakat, maka individu, organisasi atau perusahaan yang bersangkutan menerima pengampunan dan tatanan sosial budaya dapat dibangun kembali. Hearit (2006) juga menetapkan standar etika ideal yang digunakan sebagai strategi melakukan permintaan maaf dalam komunikasi krisis yaitu memenuhi kriteria Jujur, Tulus, Sukarela, Tepat Waktu, Menyasar Stakeholders Keseluruhan dan Sesuai

Konteks.

PROSES ANALISIS KASUS (CASE ANALYSIS PROCESS)

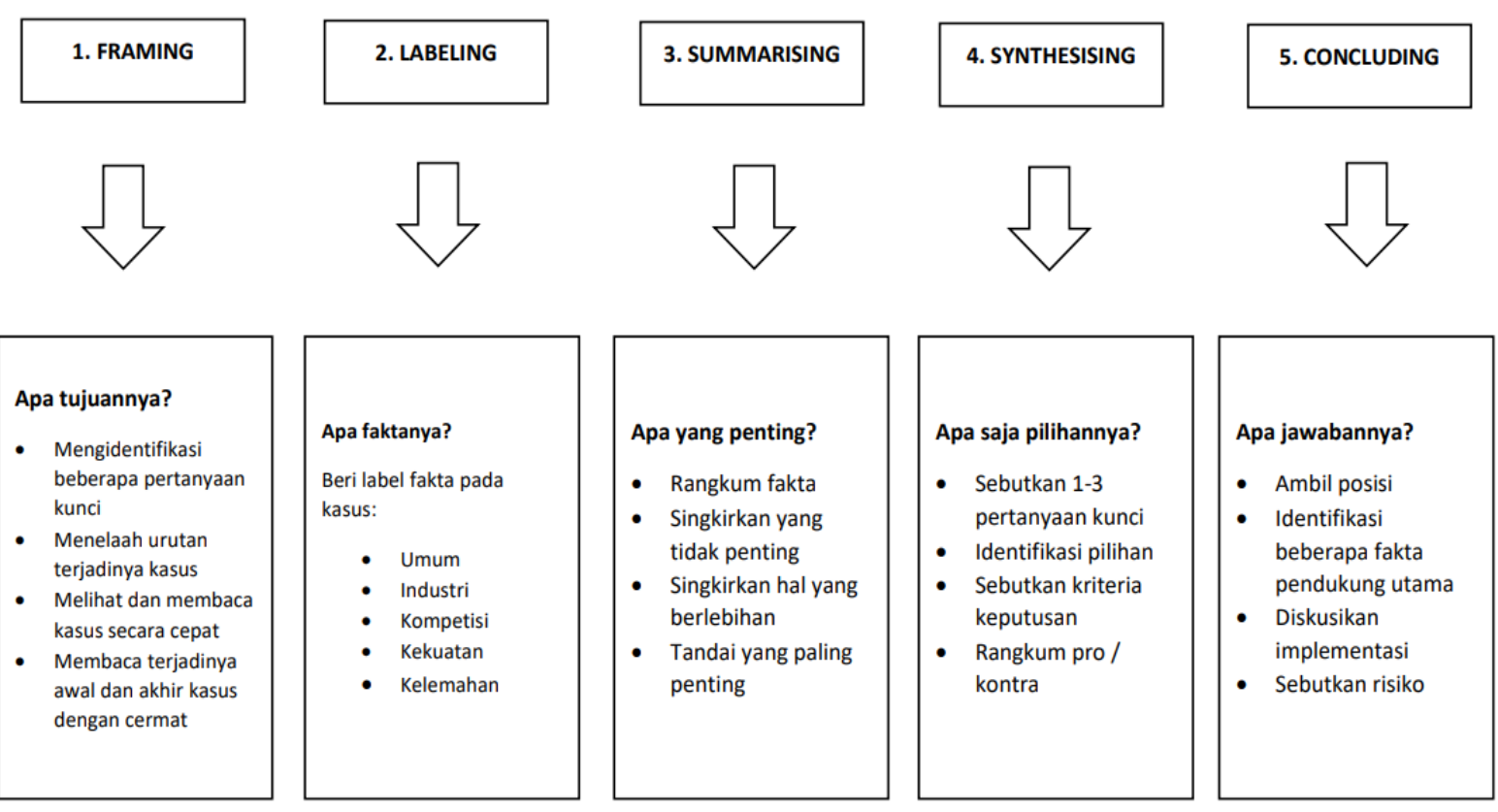




\section{METODOLOGI}

Penelitian dilakukan dengan pendekatan metode kualitatif dan metode studi kasus. Creswell (2002) menjelaskan studi kasus berfokus pada terjadinya sebuah masalah, yang setelah dipelajari akan mengungkapkan pemahaman mendalam tentang "kasus" atau sistem terbatas, yang melibatkan pemahaman tentang suatu peristiwa, aktivitas, proses dari seorang individu atau lebih. Studi kasus dapat sejalan dengan paradigma interpretivist yang mengasumsikan bahwa realitas adalah konstruksi sosial yang muncul dari cara individu dan kelompok berinteraksi (VanWynsberghe dan Khan, 2007). Studi kasus adalah bagian dari pendekatan kualitatif di mana peneliti mengeksplorasi kasus dari waktu ke waktu melalui pengumpulan data yang terperinci dan mendalam, melibatkan berbagai sumber informasi, seperti pengamatan, wawancara, materi audiovisual dan dokumen atau laporan, serta melaporkan deskripsi dan tema berbasis kasus (Creswell et al. 2007). Data yang dikumpulkan adalah data sekunder yang dikumpulkan dari berbagai artikel pemberitaan dan media sosial. Puri (2020) menjelaskan analisa krisis menggunakan proses tahapan yang dimulai dengan Framing sebagai perumusan pertanyaan kunci dan mencermati kisah terjadinya krisis, melihat pemberitaan yang muncul dalam Labelling, Summarizing atau meringkas hal-hal penting, mempersempit pertanyaan kunci dalam Synthesizing dan Concluding yang melihat resiko serta kemungkinan yang muncul setelah memutuskan langkah penyelesaian krisis. Proses tahapan ini memaparkan terjadinya sebuah kasus, menggambarkan metafora serta memberikan deskripsi atas situasi yang sedang terjadi saat ini. Tahapan metode analisis kasus yang digunakan dapat memberikan penggambaran yang lebih jelas mengenai permasalahan hingga penyelesaian krisis.

\section{ANALISIS DAN PEMBAHASAN}

\subsection{Analisis}

1. Framing; Menyusun pertanyaan kunci seperti bagaimana Hard Rock FM dapat mengembalikan reputasinya? Apakah Hard Rock FM harus menggunakan buzzer dalam mengendalikan komentar warganet di media sosial? Haruskah Hard Rock FM tetap mengadakan kegiatan tahunan Fashion Rocks setelah krisis ini terjadi? Serta haruskah Hard Rock FM tetap bekerjasama dengan lembaga, perusahaan atau pengelola lokasi umum lainnya? Fase Framing ini kemudian dapat dikaji lebih dalam melalui (a) Flipping and Skimming; Warganet kecewa karena penyelenggara terkesan menyepelekan dengan tidak cepat meminta maaf. Rekam jejak digital menyimpan sejarah krisis melalui pencarian tanda pagar \#HRFMFashionRocks dan berbagai pemberitaan online yang negatif. Hingga saat ini terdapat 411 komentar di Twitter, 299 diantaranya dalam bentuk Quote Tweets dan 650 komentar di akun Instagram @hardrockfm, (b) Beginning of Case; Penyelenggaraan kegiatan tahunan Hard Rock FM Fashion Rocks, peragaan busana pertama di Indonesia yang dilakukan di dalam gerbong MRT yang sedang berjalan dan dilakukan pada hari Jumat dan di waktu pulang kantor yaitu pukul 18.00 WIB. Indozone.id (2020) memberitakan kritik pengguna Moda Raya Terpadu (MRT) Jakarta banyak disampaikan warganet melalui platform media sosial Twitter dengan beredarnya foto serta video penyelenggaraan kegiatan serta aksi protes dari penumpang, (c) Ending of Case; Permintaan maaf secara korporat oleh Hard Rock FM dan secara pribadi oleh Head of Business Growth MRA Media, Iwet Ramadhan dan diikuti oleh pembawa acara, Gofar Hilman serta para penyiar Hard Rock FM Jakarta (Media Riau, 2020). Perusahaan juga tidak memberikan respon terhadap komentar negatif, melakukan sandwich technique yaitu 
menutup pemberitaan yang buruk dengan berita yang positif serta menggunakan bantuan buzzer untuk meninggalkan komentar baik di lini masa demi menutup komentar buruk warganet.

2. Labelling; Mengacu pada kolom pencarian Google, ditemukan 20 pemberitaan negatif yang cukup dominan. Pemberitaan yang muncul secara garis besar membahas mengenai kemarahan penumpang moda transportasi umum MRT yang menjadi korban dan keluhan warganet yang menjadi viral dalam waktu singkat.

3. Summarizing; Meringkas dengan melihat dari sisi luar atau eksternal dan sisi dalam atau internal yang dapat dijabarkan sebagai (a) Eksternal; (i) General Environment: Dengan mengadakan kegiatan Fashion Rocks di MRT yang menjadi moda transportasi baru di Jakarta dapat mempertahankan brand positioning perusahaan sebagai radio gaya hidup dewasa muda sekaligus memunculkan kesadaran publik yang diinginkan, (ii) Industry: Hard Rock FM selama puluhan tahun dikenal sebagai radio gaya hidup dan hiburan pertama di Indonesia yang memberikan berbagai informasi terkini seputar tren terkini kepada pendengarnya. Fashion Rocks menjadi pembeda perusahaan dengan bentuk media audio lain yang sedang disukai banyak orang seperti layanan musik streaming secara online, (iii) Competition: Segmentasi pendengar dewasa muda juga dimiliki oleh para kompetitor lain seperti Jak FM, Indika FM dan Motion FM. Perkembangan internet dan teknologi di zaman moderen ini membuat Hard Rock FM juga harus bersaing dengan Podcast dan layanan musik streaming online. Secara grup perusahaan, Hard Rock FM yang bernaung dalam MRA Media memiliki kompetitor Mahaka Group, (b) Internal; (i) Strenghts: Reputasi dan citra Hard Rock FM sudah terbentuk tegas dan kuat sebagai radio gaya hidup dewasa muda ditambah penyiar-penyiar yang juga menjadi influencer di tengah masyarakat. Hard Rock FM juga memiliki posisi yang kuat dan aktif di media sosial milik perusahaan dan para penyiarnya, (ii) Weaknesses: Gaya hidup yang ditampilkan dan disajikan oleh Hard Rock FM tidak sesuai dengan target pendengar. Sebagai media audio yang menggunakan gelombang audio, rentan mengalami gangguan dan sifat siaran radio tidak dapat ditarik ulang.

4. Synthesizing; Tahapan yang dijabarkan melalui Tabel 1 ini melihat pada opsi yang diberikan terhadap beberapa pertanyaan kunci yang diajukan seperti Hard Rock FM dapat melakukan permintaan maaf untuk mengembalikan reputasinya dari krisis ini, menggunakan buzzer dalam mengendalikan komentar warganet di media sosial, sebaiknya tidak mengadakan kegiatan tahunan Fashion Rocks setelah krisis terjadi mengingat publik masih mengingat dan trauma atas kejadian penyelenggaraan peragaan busana di moda transportasi umum ini dan dapat tetap bekerjasama dengan lembaga, perusahaan atau pengelola lokasi umum lainnya untuk mengadakan kegiatankegiatan yang lebih bersahabat dengan publik.

\section{Concluding;}

Tidak hanya mengucilkan pengguna transportasi umum MRT, Hard Rock FM juga tidak memperhitungkan reaksi warganet hingga membuat keluhan tersebut berubah sebagai krisis akibat dilakukan pada waktu yang tidak tepat. Dengan perkembangan media sosial, krisis ini berpengaruh pada citra dan reputasi yang berimbas pada kepercayaan stakeholders terutama pengiklan dan jatuhnya citra perusahaan di mata kompetitor. Saat krisis terjadi perusahaan tidak merespon semua komentar negatif untuk tidak memperluas kemarahan publik hingga akhirnya mengeluarkan pernyataan maaf secara terbuka melalui media sosial. Perwakilan top level management, Iwet 
Ramadhan selaku Head of Business Growth MRA Media juga meminta maaf secara pribadi di kolom komentar. Sikap Iwet Ramadhan yang juga dikenal masyarakat sebagai public figure berhasil meyakinkan dan menenangkan, hingga Hard Rock FM menutup berbagai keluhan dengan memanfaatkan buzzer yang memberikan respon positif serta sandwich technique dengan memposting foto atau video lain dalam lini masa media sosial mereka.

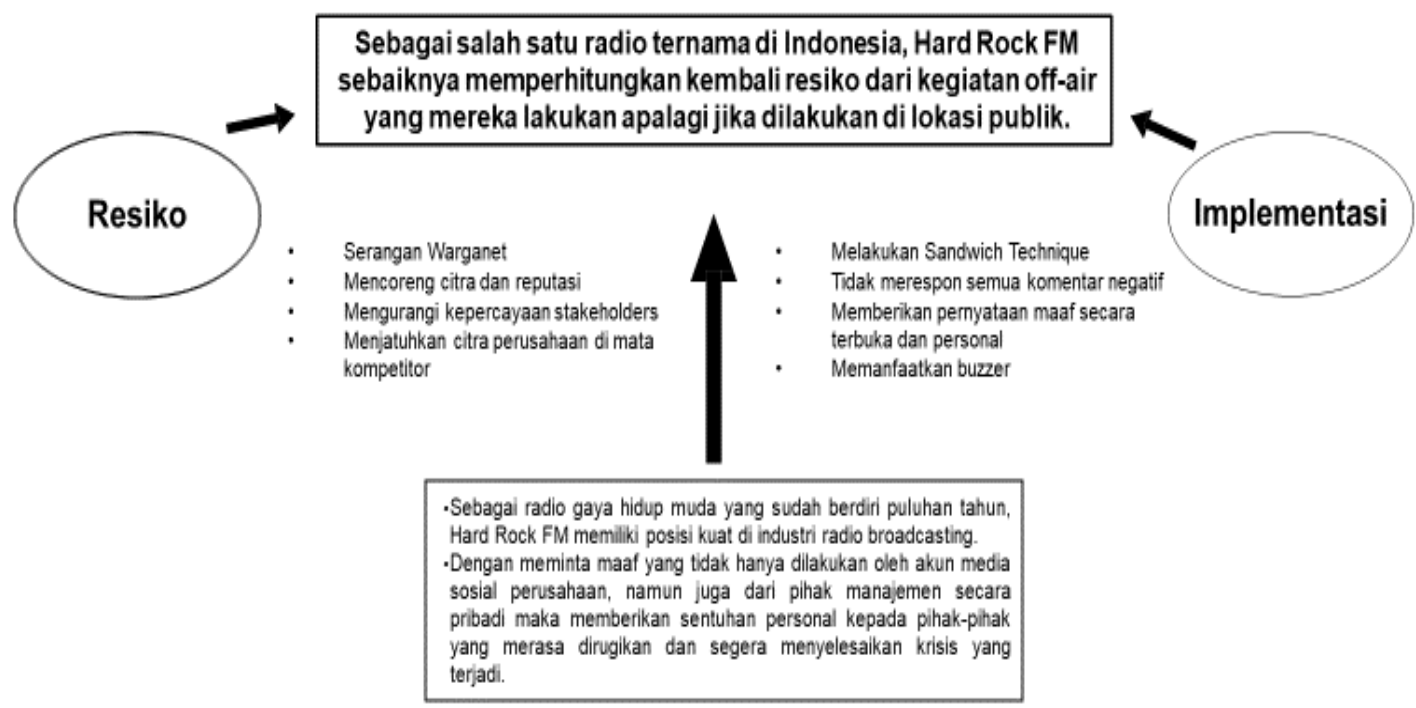

Skema 1. Resiko dan Implementasi

\subsection{Pembahasan}

Lorenz (2000) melalui Chaos Theory and The Butterfly Effect in Crisis Management menyampaikan perlunya kepekaan karena sebuah aksi kecil dapat menciptakan efek yang lebih besar dan tidak terduga. Aksi warganet yang mengeluhkan Fashion Rocks 2020 berbuntut panjang dengan viralnya berbagai foto dan video di media sosial sehingga menimbulkan kemarahan

pengguna media sosial lain dan menjadi krisis. Melihat lima tahapan proses permintaan maaf Hearit yang dikemukakan Frandsen dan Johansen (2017) maka krisis yang dialami oleh Hard Rock FM ini dapat dianalisa sebagai (1) Adanya pelanggaran tatanan sosiokultural oleh individu, organisasi atau perusahaan karena tindakan kesalahan tertentu; Kegiatan Fashion Rocks 2020 yang diadakan oleh Hard Rock FM di moda transportasi umum MRT Jakarta dianggap telah melanggar tatanan sosiokultural yang merugikan masyarakat pengguna MRT di jam pulang bekerja di Jumat sore, (2) Individu, organisasi atau perusahaan yang bertanggung jawab atas pelanggaran dituduh melakukan perbuatan salah oleh masyarakat; Hard Rock FM sebagai penyelenggara kegiatan Fashion Rocks 2020 menjadi sasaran kesalahan oleh pengguna MRT yang menyebarkan informasi melalui media sosial hingga viral dan ditanggapi dengan banyaknya reaksi negatif oleh warganet, (3) Akibat tuduhan tersebut, timbul krisis legitimasi sosial antara pelaku yang bertanggung jawab atas perbuatan salah dan masyarakat (Teori Legitimasi Sosial Perusahaan); Sebagai perusahaan atau organisasi, Hard Rock FM berada di posisi yang tetap bergantung pada lingkungan sekitarnya. Sebagai radio ternama dengan segmentasi gaya hidup dewasa muda, sangat penting untuk tetap menjaga nama baik perusahaan di lingkungan masyarakat untuk menjaga 
reputasi dan kinerja bisnis perusahaan. Hard Rock FM hanya dapat bertahan selama dapat meyakinkan lingkungan sekitarnya bahwa kegiatan Fashion Rocks 2020 yang diadakan telah berjalan dengan cara yang benar dan sesuai, (4) Individu, organisasi, atau perusahaan yang bertanggung jawab atas kesalahan tersebut meminta maaf dan mengakui atas kesalahannya; Walaupun dianggap tidak selalu efektif, meminta maaf tetap menjadi senjata yang penting dalam komunikasi krisis (Kesetovic et al. 2014). Untuk menyelesaikan krisis ini, Hard Rock FM sebagai penyelenggara dan penanggung jawab kegiatan telah berusaha menyampaikan permintaan maaf melalui akun media sosial yang dimiliki. Namun dalam hubungan organisasi-publik, masyarakat umumnya jarang dapat menerima permintaan maaf seperti yang mereka lakukan ketika memaafkan teman, keluarga atau pasangannya.

Lee dan Chung (2012) menyatakan hal ini disebabkan oleh rendahnya tingkat kepercayaan dan tingginya keraguan masyarakat kepada organisasi atau perusahaan besar yang telah melakukan kesalahan dan lebih dianggap sebagai retorika yang berbunga-bunga. Oleh karena itu, organisasi atau perusahaan harus tetap berhati-hati dalam menyampaikan permintaan maaf kepada masyarakat umum dengan mempertimbangkan penggunaan simpati yang tinggi dalam kaitannya dengan sikap ingin bertanggung jawab. Masih banyaknya warganet yang menyampaikan protes membuat Iwet Ramadhan sebagai Head of Business Growth MRA Media memberikan permintaan maaf secara pribadi melalui kolom komentar. Jika melihat dari empat konfigurasi structural permintaan maaf yang disampaikan oleh Tavuchis (1991) maka bentuk penyelesaian krisis yang diwakili petinggi perusahaan ini masuk ke dalam permintaan maaf interpersonal dari satu individu ke individu lain atau One to One, dan (5) Jika permintaan maaf diterima dan dianggap benar oleh masyarakat, maka individu, organisasi atau perusahaan yang bersangkutan menerima pengampunan dan tatanan sosial budaya dapat dibangun kembali; Tindakan Iwet Ramadhan yang juga dikenal sebagai public figure mendapat respon yang baik dari warganet dan mampu meredam krisis. Untuk menghilangkan perhatian warganet, Hard Rock FM memanfaatkan buzzer untuk memberikan komentar positif yang menutup rangkaian komentar negatif dan melakukan sandwich technique.

Dalam enam standar kriteria etika ideal Hearit (2006), strategi permintaan maaf dalam komunikasi krisis Hard Rock FM dapat dianalisa dengan (1) Jujur; Hard Rock FM dan Iwet Ramadhan mewakili manajemen melakukan permintaan maaf dengan tidak berkilah, menipu atau berbohong dan bersikap terbuka melalui media sosial, (2) Tulus; Niat baik ditunjukkan dengan menyampaikan permintaan maaf melalui media sosial dan menyasar langsung kepada pengguna MRT serta warganet yang merasa dirugikan atau telah menyampaikan protes dengan meminta maaf secara pribadi di kolom komentar dari warganet di lini masa media sosial, (3) Sukarela; Permintaan maaf dilakukan sendiri secara sukarela oleh pihak perusahaan dan manajemen tanpa adanya tuntutan dari warganet, (4) Tepat Waktu; Hal ini menjadi kekurangan pihak perusahaan dalam menanggapi krisis yang terjadi di media sosial. Mungkin disebabkan karena perusahaan tidak menyangka akan terjadi krisis di media sosial dan belum merumuskan jawaban atau tanggapan yang tepat untuk merespon. Sehingga dari sudut pandang warganet, perusahaan sedikit terlambat menyampaikan permintaan maaf dan meremehkan kejadian ini, (5) Menyasar Stakeholders Keseluruhan; Permintaan maaf telah ditujukan kepada seluruh stakeholders terkait, baik itu pengguna jasa layanan MRT yang secara langsung telah dirugikan, maupun warganet yang secara tidak langsung tersulut kemarahannya akibat kesalahan penyelenggara, (6) Sesuai 
Konteks; Permintaan maaf disampaikan dalam konteks yang sesuai dan mudah diakses oleh semua stakeholders, yaitu melalui media sosial Instagram dan Twitter milik perusahaan.

\begin{tabular}{|c|c|c|c|c|}
\hline tion & $\begin{array}{c}\text { Option / } \\
\text { Hypothesis }\end{array}$ & Decision Criteria & Pros & Cons \\
\hline $\begin{array}{l}\text { la Hard } \\
\text { dapat } \\
\text { palikan } \\
\text { lya? }\end{array}$ & $\begin{array}{l}\text { Meminta } \\
\text { maaf }\end{array}$ & $\begin{array}{lrr}\text { Publik yang marah tidak } \\
\text { peduli dengan alasan dan } \\
\text { sikap } & \text { menyepelekan. } \\
\text { Mereka } & \text { hanya } & \text { butuh } \\
\text { respon } & \text { cepat } & \text { dan } \\
\text { permintaan maaf. } & \end{array}$ & $\begin{array}{l}\text { - Menunjukkan itikad } \\
\text { baik Hard Rock FM } \\
\text { (MRA Media) sebagai } \\
\text { penyelenggara. } \\
\text { - Mencegah kemarahan } \\
\text { netizen berkembang } \\
\text { luas. }\end{array}$ & $\begin{array}{l}\text { - Menunjukkan Hard Rock } \\
\text { FM (MRA Media) sebagai } \\
\text { pihak yang lemah. } \\
\text { - Mengurangi kepercayaan } \\
\text { dari stakeholders } \\
\text { (pengiklan dll). } \\
\text { - Menjatuhkan } \\
\text { perusahaan di r mata } \\
\text { kompetitor. }\end{array}$ \\
\hline akan & Iya & $\begin{array}{l}\text { Sebagai garda penjaga citra } \\
\text { perusahaan di media } \\
\text { sosial. }\end{array}$ & $\begin{array}{l}\text { Melindungi perusahaan } \\
\text { dari komentar negatif. } \\
\text { Mengangkat citra yang } \\
\text { diharapkan perusahaan } \\
\text { dilihat oleh pengguna } \\
\text { media sosial lainnya. }\end{array}$ & $\begin{array}{l}\text { - Kadang Buzzer tidak sesuai } \\
\text { dengan segmen atau image } \\
\text { perusahaan. } \\
\text { - Dapat diketahui Buzzer } \\
\text { bayaran yang sengaja } \\
\text { digunakan untuk } \\
\text { melindungi perusahaan. } \\
\text { - Membutuhkan biaya. }\end{array}$ \\
\hline $\begin{array}{l}\text { kan } \\
\text { locks? }\end{array}$ & Tidak & $\begin{array}{l}\text { Publik masih mengingat } \\
\text { kesalahan } \\
\text { penyelenggaraan Fashion } \\
\text { Rocks } 2020 .\end{array}$ & $\begin{array}{l}\text { - Melindungi perusahaan } \\
\text { dari komentar negatif. } \\
\text { - Mengangkat citra yang } \\
\text { diharapkan perusahaan } \\
\text { dilihat oleh pengguna } \\
\text { media sosial lainnya. }\end{array}$ & Kehilangan event ikonik. \\
\hline $\begin{array}{l}\text { ama } \\
\text { an atau } \\
\text { lum }\end{array}$ & Iya & $\begin{array}{l}\text { Tetap mengadakan } \\
\text { kegiatan off air yang lebih } \\
\text { bersahabat dengan publik. }\end{array}$ & $\begin{array}{l}\text { - Menjalin hubungan } \\
\text { baik dengan } \\
\text { stakeholders. } \\
\text { - Menciptakan kegiatan } \\
\text { atau ide kreatif lain. }\end{array}$ & $\begin{array}{ll}\text { Dapat kembali dikaitkan } \\
\text { dengan kasus yang pernah } \\
\text { terjadi. }\end{array}$ \\
\hline
\end{tabular}




\section{KESIMPULAN DAN IMPLIKASI}

Melalui pembahasan sebelumnya, dapat disimpulkan bahwa perusahaan belum memiliki sensitivitas yang baik terhadap keberadaan dan kekuatan warganet. Sebagai radio gaya hidup, fokus perusahaan hanya kepada penyelenggaraan kegiatan demi menarik perhatian publik namun mengesampingkan kepentingan pengguna jasa transportasi.

Namun sikap meminta maaf yang dilakukan oleh top level management menjadi pilihan yang sangat tepat. Sesuai dengan salah satu konfigurasi struktural permintaan maaf Tavuchis (1991) yaitu One to One, interpersonal dari satu individu ke individu lain, dalam pelaksanaan permintaan maaf perusahaan dan penyelesaian krisis komunikasi, melalui hubungan interpersonal yang erat membuat pihak yang dirugikan cenderung akan memaafkan ketika menerima permintaan maaf yang tulus, yang dalam hubungan organisasi-publik, masyarakat mungkin tidak menunjukkan belas kasihan yang sama (Lee dan Chung, 2012).

Adapun saran yang dapat diberikan adalah dengan lebih cepat menyampaikan permintaan maaf atas kesalahan yang tentu dapat menunjukkan empati serta sensitivitas terhadap reaksi yang diberikan warganet mengingat penyebaran pesan melalui media sosial semakin mudah dilakukan. Ada baiknya pihak admin atau moderator media sosial perusahaan sudah memiliki rancangan jawaban atau pesan yang dapat digunakan jika menghadapi krisis di media sosial sehingga respon dapat disampaikan dengan lebih cepat. Namun dalam hal ini perusahaan juga perlu memperhatikan perumusan pesan permintaan maaf yang baik dan tidak hanya berfokus pada pemilihan kata-kata namun juga harus sesuai dengan elemen non-verbal komunikasi dan konteks keseluruhannya (Kesetovic et al., 2014). Selain itu perlu dilakukan perencanaan yang lebih baik mengenai segala kemungkinan yang terjadi dalam penyelenggaraan sebuah event atau kegiatan off-air yang dilakukan di lokasi publik.

\section{DAFTAR PUSTAKA}

Asosiasi Penyelenggara Jasa Internet Indonesia (APJII). 2019. Penetrasi dan Profil Perilaku Pengguna Internet Indonesia. Diakses 29

Maret 2020 dari https://apjii.or.id/survei.

Coombs W. T. 2009. Conceptualizing Crisis Communication. In: Heath R.L dan O'Hair H. D. The Handbook of Risk and Crisis Communication. Routledge. New York.

Coombs W. T. 2015. Ongoing Crisis Communication: Planning, Managing, and Responding. SAGE Publications. USA.

Creswell J. 2002. Research Design: Qualitative, Quantitative and Mixed Method Approaches. Sage. London.

Creswell J. W., et al. 2007. Qualitative Research Designs: Selection and Implementation. The

236- 264. Counseling Psychologist. 35 (2):

Damayanti A. 2020. Paracrisis and Social Media: A Social Network Analysis of Hashtag \#uninstallbukalapak on Twitter. Jurnal Komunikator. 12 (1): 24-36.

Frandsen F dan Johansen W. 2017. The Apology of a Sports Icon: Crisis Communication and Apologetic Ethics. HERMES - Journal of Language and Communication in Business. 20 (38): 85-104.

Fuchs C. 2017. Social Media: A Critical Introduction. SAGE Publications. London.

Hamdan N. 2019. Pengguna Instagram di Indonesia Terbesar ke-4 Dunia. Diakses 29 Maret 2020 dari www.tagar.id/pengguna-instagramdi-indonesia-terbesar-ke4-dunia.

Hearit K. M. 2006. Crisis Management by Apology Corporate Response 
to Allegations of Wrongdoing. Lawrence Erlbaum Associates. New Jersey.

Indozone.id. 2020. Ada Fashion Show di Gerbong MRT, Cuitan Protes Netizen Viral. Diakses 21 Desember 2020 dari www.indozone.id/news/4Ws1Q8/a da-fashion-show-di-gerbong-mrtcuitan-protes-netizen-viral/read-all.

Je Cho S. 2012. The Proceedings of the 12th International Congress on Mathematical Education. Springer. Seoul.

Kesetovic Z, Toth I dan Korajlic N. 2014. Apology as Crisis Communication Strategy- Importance of Cultural Context. Coll. Antropol. 38 (1): 171- 178.

Lee S dan Chung S. 2012. Corporate Apology and Crisis Communication: The Effect of Responsibility

Admittance and Sympathetic Expression on Public's Anger Relief. Public Relations Review. 38 (1): 932-934.

Lorenz E. 2000. The Butterfly Effect. In: Abraham R dan Ueda Y. The Chaos Avant-garde: Memories of the Early Days of Chaos Theory. World Scientific. Singapore.

Media Riau. 2020. Gofar Hilman Minta Maaf Selaku MC Fashion Show di MRT. Diakses 21 Desember 2020 dari https://mediariau.com/berita/gofar -hilman-minta-maaf-selaku-mc- show-di-mrt.

Miller D., et al. 2016. How the World Changed Social Media. UCL Press. London.

Puri S. 2020. Effective learning through the case method. Innovations in Education and Teaching International. 57 (1): 1-11.

Shapiro B. P. 1984. Introduction to Cases. Harvard Business School Background Note. Massachusetts. Smartsheet.com. 2021. Models and Theories to Improve Crisis
Management. Diakses 9 Februari 2021 dari https://www.smartsheet.com/conte nt/crisis-management-modeltheories.

Suryani I dan Sagiyanto A. 2018. Strategi Manajemen Krisis Public Relations PT Blue Bird Group. Journal Communication Budi Luhur. 9 (1): 102-113.

Tavuchis N. 1991. Mea Culpa: A Sociology of Apology and Reconciliation. Stanford University Press. Stanford.

Ulmer R.R, Sellnow T.L dan Seeger M. W. 2019. Effective Crisis Communication: Moving From to Opportunity. 4th ed. SAGE Publications. California.

VanWynsberghe R dan Khan S. 2007. Redefining Case Study. International Journal of Qualitative Methods. 6 (2): 80-94.

We Are Social \& Hootsuite. 2020. Digital 2020: Global Digital Yearbook. Diakses 21 Desember 2020 dari https://datareportal.com/reports/d igital-2020-indonesia.

Zaenudin A. 2019. \#UninstallBukalapak \& Blunder CEO Bukalapak, Lalu Selanjutnya Apa? Diakses 21 Desember 2020 dari https://tirto.id/uninstallbukalapakblunder-ceo-bukalapak-laluselanjutnya-apa-dg7A. 